\title{
Oil Factor in the Formation of the US-Azerbaijani Relations and Effective Use of Oil Revenues
}

\author{
Khatira F. Heydarova ${ }^{1}$ \\ ${ }^{1}$ The Institute on Human Rights, National Academy of Sciences of the Republic of Azerbaijan, Baku, the \\ Republic of Azerbaijan \\ Correspondence: Khatira F. Heydarova, The Institute on Human Rights, National Academy of Sciences of the \\ Republic of Azerbaijan, Vung-Tau Street 6A, fl. 53, Khatai District, Baku, AZ 1000, the Republic of Azerbaijan. \\ Tel: 99-45-5577-1211. E-mail: khatira.heydarova@yahoo.com
}

Received: September 7, 2014 Accepted: October 27, $2014 \quad$ Online Published: December 20, 2014

doi:10.5539/ass.v11n2p219 URL: http://dx.doi.org/10.5539/ass.v11n2p219

\begin{abstract}
The USA is particularly interested in the development of multilateral cooperation with the Republic of Azerbaijan that acts as an initiator of new projects which forms the energy security maps of Europe and realizes energy projects of global and regional significance. Azerbaijan also in its turn attaches great importance to the relations with the United States of America that has a say in global processes and in the establishment of the new world order. These relations that have been established based on the cooperation in the field of oil cover various spheres such as security, human rights and protection of democracy, fight against international terrorism. Stimulus given for the development of these relations by the exploitation of rich hydrocarbon resources of Caspian Sea and the results of wise use of obtained oil revenues for Azerbaijan were reviewed in the article.
\end{abstract}

Keywords: crude oil, pipeline strategy, BTC, oil revenues, human capital

\section{Introduction}

The USA is the biggest energy user of the world. Since 2011, daily oil consumption of USA is 19 million barrels (http://en.wikipedia.org/wiki/List_of_countries_by_oil_consumption). If we take European Union as a whole for comparison, in this case this figure has been estimated approximately 14 million barrel. Although the USA is one of the countries that produce oil, it imports about 10 million barrels oil per day due to high demand for energy. Taking into consideration aforementioned, we can assume that oil is an issue with strategic significance for USA and after being caught unprepared for oil crisis of 1973, the USA was always in search for new oil zones using every opportunity and tried to take those areas under its patronize. It is true that USA is in search of new different alternative energy sources taking into consideration the probability of depletion of natural resources such as oil and gas in XXI century. However, oil retains its importance as main energy means.

Rich oil and gas reserves of Azerbaijan had attracted the attention of U.S. companies even in the nineteenth century, but the long-term presence of Russian domination discouraged them from using this feature. The collapse of the Soviet Union opened new opportunities in the region. On the other hand, after the collapse of the Soviet Union, and the acquisition of independence, Azerbaijan had faced a number of problems, and large amounts of money needed for the transition to an open market economy, so the country has opened its doors to the major Western companies. It was a very thought out step, and today we can see the fruits of this collaboration. If you have compared the position of Azerbaijan 20 years before with the current situation, you can easily feel the high level of development.

\section{Formation of Initial Relations between USA-Azerbaijan}

If we will have a look at the history of the relations between Azerbaijan and United States of America, we can witness the existence of these relations since $70-80^{\text {th }}$ of XIX century. That period coincides with the phase when the oil industry developed in Baku. At that time, sale of Caspian oil was in the authority of "Standard Oil" Company belonging to Rockefeller who was American businessman in Russian market. After a while a company belonging to Nobel brothers began to push Rockefeller from Russian market. Competition and conflicts between European states and the USA did not enable the permanent location of Rockefeller in Baku (Bunyadov, 1994). As the English had more powerful position in Azerbaijan before the Americans, as well, it created obstacles for 
the establishment and development of economic relations between USA and Azerbaijan related to the discrepancies between USA- England.

Interest for region began to decrease in the beginning of XX century. October revolution of 1917 increased interest of the USA and western states for South Caucuses. However the USA being afraid of the disintegration of Russia, and did not tend to provide financial assistance for Trans Caucasus commiserate. And after a while, Trans Caucasus Federation was released and on May 28, 1918 Azerbaijan Democratic Republic (ADR) firstly declared its independence being first democratic republic in the East. First political step of Azerbaijan Democratic Republic was to give information about its newly established state to world countries, as well as, the USA. (Ismayilov, Hasanov, \& Gafarov, 1995)

However, that period was the most intense period of the international relations: First World War had just finished, it was very difficult for small states that had just declared their independence to establish relations with super powers of the world. At that time, ADR tried to establish relations with a number of states by means of Foreign Affairs Department of the Ottoman Empire and as well with the USA. On October 16, the head of state Fatali khan Khoyski and minister of foreign affairs Adil Ziyadkhan applied to Woodrow Wilson, the president of USA via telegraph. Assistance of the USA president for the recognition of the independence of Azerbaijan Democratic Republic by world states was noted in the application. After this application the official representatives of the USA, England and France declared that they wanted to establish "de-facto" relations with Azerbaijan. (Hasanli, 1993)

In 1919 Versailles Peace Conference was recalled related to the results of First World War and Azerbaijan was also invited to the conference. A special commission consisting of 30 persons was established by the decision of the Conference of Versailles to study the political and economic situation in the region to the south of Russia. Just to investigate the condition in the Caucasus region was assigned to American Colonel Benjamin Burcheg Moor.

At that time, western states, including the USA has little information related to Azerbaijan. For that reason our delegation to Paris Peace Conference prepared a document reflecting a lot of information about the territory, population, economic and financial condition of our country and submitted it to Woodrow Wilson and the officials of other western states. Max Robinson, the head of one of the famous companies of America made negotiations about the sale of crude oil and the import of American products to Azerbaijan with the delegation of Azerbaijan.

Initiative to establish first diplomatic relations between the USA and ADR were made in Paris on May 28, 1919. Representatives of Azerbaijan met with W. Wilson and Morgenthau who was the Ambassador of USA to Turkey during war. Morgenthau expressed opinion on the issue that the direction of American investment to this country can be successful for the evaluation of natural resources and economic potential of Azerbaijan.

Despite all of the efforts, W. Wilson did not have positive approach for the development of relations between these two states related to the existence of powerful impact of the English in Azerbaijan and on the other hand Armenian lobby in USA which was powerful since that period. (Gassimov \& Abdullayev, 1998) Nevertheless the USA established its consulate in Azerbaijan and developed economic relations.

In 1989-1991, as a result of the occurrence of processes that were able to radically change the system of International Relations, a number of states found their independence and began to conduct independent policy. On October 18 of 1991 after declaring its independence again the Republic of Azerbaijan highlighted the importance of the formation and implementation of new foreign policy course complying with the national statehood principles as an important matter. At the end of 1991 and in 1992, recognition of Azerbaijan by world states in a consistent manner and establishment of diplomatic relations enabled to its rapid integration to the system of international relations.

One of the states that firstly recognized Azerbaijan Republic after restoration its independence was the United States. The US' President George Bush declared the recognition of the independence of Azerbaijan while giving disclosure related to the condition newly established in the world on December 25, 1991. However though he recognized all of the states that were newly established, but declared that he would established diplomatic relations only with some of them: official diplomatic relations will be established with Ukraine, Armenia, Kazakhstan, Belarus and Kirghizstan and with other states-Moldova, Turkmenistan, Azerbaijan, Tajikistan, Georgia and Uzbekistan, it was envisaged that diplomatic relations with them would be established in a period when those states would comply with the democracy and security principles of USA (Bush, 1991). After this declaration, President Bush sent a letter with the same content to the heads of those countries and noted that in the initial phase, USA will limit its activity by establishing diplomatic relations with 5 states which are 
mentioned above.

However USA soon felt that as a result of this policy taken by it the gap emerged in a region that has rich natural resources like Caspian Sea by the collapse of Soviet Union can be filled on the one hand by Iran and on the other hand Russia and therefore it decided to make changes in its policy by some steps.

\section{Development of Relations after Restoration of the Independence of the Republic of Azerbaijan}

According to the estimations of scientists, Azerbaijan has approximately 5 milliard tons and 5-6 trillion $\mathrm{m}^{3}$ gas reserves. And this is approximately $4 \%$ of world energy resources (Hasanov, 2005). These figures in national level can be assessed as a very great resource in terms of number of country's population, its territory, internal demand and it especially affects the position of Azerbaijan among world states.

During the first years of our independence history, increase in oil and gas production was seen as one of the main means of the removal of economic and social difficulties in front of country. At such condition, the limitation of financial resource made it strategic necessity to involve foreign companies and investors. At that time, the first company of the USA was "Amoco" that had interest for Azerbaijani oil. Company won the bid for Azeri field in January of 1991. In July there was established consortium in which attended "UNOCAL", "BP/Statoil", "McDermott" and "RAMCO" for the operation of that oil field under the direction of "Amoco" Company. However in the beginning of $90^{\text {th }}$ war condition between Armenia-Azerbaijan hindered the foreign investment flow to our country. As a result of the Amendment no. 907 to Freedom Support Act that was adopted by USA Congress in 1992 that prohibits each type of assistance in state level by United States of America, "Amoco" obliged to give the management of the above mentioned Consortium to "BP" that represents England.

Soon in the second half of 1993 there was the change of government in Azerbaijan and Heydar Aliyev-a personality having experience in the management structures of an empire such as USSR came to power. In a short time, there was stability in a country and measures were taken for the involvement of foreign capital into country's industry. Its first great success entered into history as "Contract of the Century" on September 20, 1994 and was to succeed in signing contract joined by large companies of west (The Contract of the Century). Just in that phase the importance of this contract for Azerbaijan should be assessed as vitally important.

In the contract that was regarded as "the beginning of new period in South Caucasus" by Y. White, the representative of USA, "Amoco", "Pennzoil", "Mac Dermott" companies of USA participated and accordingly they owned finished product sharing of $17,01 \%, 9,81 \%$ and $2,45 \%$.

In 1997 first official visit of President Heydar Aliyev to USA stimulated to the development of Azerbaijan-USA relations in energy sector. In August 1, 1997 there were signed contracts amounting 10 billion dollars related to the production and consumption of oil between two countries by the mediation of Albert Gore, vise -president of USA in White House, more exactly between Chevron, Exxon and Mobil petrol companies of USA and State Oil Company of Azerbaijan.

After achieving in largest shareholder in the exploitation of hydrocarbon fields of the Caspian Sea, the USA began to work on by which means these resources can be marketed into the world market. This should be such a way that there could be passed nor Russia from north nor Iran from south. If the main reasons for not passing from Russia were Russian- Chechen conflict, on the other hand it was USA's interest in the transportation of crude oil to Europe without being dependent on Russia, without having control of Russia. When coming to Iran, USA thought that it would be dangerous to transport oil through that country with whom was in conflict for a long time.

The project on the transportation of oil over Armenia to Turkey supported by the USA of course didn't coincide with the interests of Azerbaijan. And finally, the construction of Baku-Tbilisi-Ceyhan (BTC), that's a line to Turkey through Georgia was considered appropriate that coincided with the interests of both the USA and Azerbaijan. First party that expressed its strong opinion on the project was Russia. Russia making excuses that BTC will be implemented at the expense of great financial resources and Caspian Sea does not have so much oil reserves supported the transportation of Caspian oil by Baku-Novorossiysk pipeline that was operating since 1997.

In October of 1998, the USA, Azerbaijan, Turkey, Georgia, Kazakhstan and Uzbekistan gave support for BakuCeyhan pipeline by signing Ankara Declaration. One of the most important events related to Baku- Ceyhan was Europe Security and Cooperation Conference held in Istanbul in November of 1999. Leaders of Turkmenistan, Azerbaijan, Georgia, Kazakhstan and Turkey states declared that they also support this project with official document signed by Bill Clinton, the US' President. This pipeline was put into operation since May of 2005. Approximately 10 million barrel oil was required for filling pipeline. First tanker loaded with import crude oil 
transported by the pipeline was sent off on June 4 of 2006. In this project US' Companies "UNOCOL" had 8.9\% share, "Conoco Philips" 2.5\% and "Amerada Hess" 2.36\%. Though initial price of BTC pipeline project was envisaged in the amount of 2.95 milliard USA dollars, then this figure reached to 4.3 milliard dollars and when taking into consideration bank costs, it is known that this covers 5 milliard dollars of costs. However though all of these, we could say that United States of America gave great importance to strategic significance rather than economic benefit of BTC. To be superior in the competition with Russia in Caspian region and reduce the effect of Iran that is another state of the region was considered more important for it (Frederick \& Cornell, 2005).

So, one of the main points that conditioned the development of USA- Azerbaijan relations is Azerbaijan's being the country rich with hydrocarbon resources, as well as, main transit country where these resources are transported. America is currently the leading state that gives support for the realization of new trans-energy-communication projects organized by Azerbaijan.

At the end of the last year, the most important support for signing agreement on the realization of Trans Anatolian Gas Pipeline (TANAP) that became an important economic situation in recent history by the joint initiative of Azerbaijan and Turkey was came from Washington. During previous years, USA which participated directly in the realization of trans-energy corridors that have strategic importance in the regions considered TANAP project as main arteries in the diversification of energy routes and a main point of modern energy geography. After signing agreement related to that project, the US' government made a statement that especially appreciated the enhancement of energy routes range of which Azerbaijan was their author. Hillary Clinton, US' Secretary of State highly appreciated the agreement signed on the gas transit between Turkey and Azerbaijan and emphasized that the transported fuel would lead to strengthening wide cooperation format in the region and consolidation of security network system. As it can be seen, United States highly appreciated such significant steps of Azerbaijan and Turkey that became into the warrant of peace network in the region ad that is the guarantor of peace, stability and security in South Caucasus region.

\section{From "Oil Capital" to "Human Capital"}

Today countries giving high value to their population are accepted as the most developed countries. In 2000,8 priority objectives were determined in the program of "Millennium Development Goals" adopted by UNO for the provision of future sustainable development and most of them are related to the sustainable development of human capital (The Millennium Development Goals, 2000). Just for this reason development of human capital became priority issue for Azerbaijan, as well as, most world countries.

The term "Human capital" was brought into scientific revolution in the middle of XX century and it is mostly used as an economic concept. Creators of relevant conception were Theodor Shultz and Harry Becker, American economists, laureates of Nobel award in the field of economic. According to Harry Becker, many theories explicitly connect investment in human capital development to education, and the role of human capital in economic development, productivity growth, and innovation has frequently been cited as a justification for government subsidies for education and job skills training (Schultz, 1981).

Today main priority of internal policy of our country is the economic diversification, that's decreasing the dependence of economy from energy field and provision of sustainable development of the state. As oil and gas is exhaustible resource. It is right that according to the estimations of scientists, hydrocarbon resources of Caspian Sea will be enough up to 100 years. However the foundation of the proper strategy was put for the process of turning "black gold" that's oil to human capital. In the first case, Heydar Aliyev, who was the third President of the country established State Oil Fund by the decree signed on December 29, 1999 in order to maintain the issue of proper and efficient use of revenues obtained from oil always in the center of attention. The establishment of fund was envisaged as a mechanism of collection of revenues and effective use from it which is obtained related to the implementation of oil agreements (State Oil Fund of the Republic of Azerbaijan).

Here the prevention of the cases that can lead to the wastefulness in the use of revenues obtained from oil and gas resources, as well as, fully provision of transparency was highlighted. Main directions of the activity of fund was to stimulate the development of the country's economy, finance energy projects that have strategic importance, as well as, important social project, to maintain funds obtained from oil for present and future generations and to increase, at the same time, to provide the transparency principle in the production.

In 2003, Azerbaijan State Oil Fund that joined to transparency initiative in the mining industry of Great Britain regularly gives information to public about the received and spent funds. During 2001-2011, totally 56.5 milliard USA Dollars were received in Oil Fund and 30.4 milliard USA dollars of this fund, that's $53.8 \%$ were directed at the savings. 
In 2007 the State Oil Fund won the 2007 UN Public Service Award and in February 2009, Azerbaijan became the first country to achieve compliance under the Extractive Industries Transparency Initiative. (http://www.afaz.org/azerbaijan-and-united-states-tested-and-proven-allies/)

In October of 2010, Azerbaijan ranked $9^{\text {th }}$ among 41 countries in the report on the transparency index in the management of natural resources published jointly the organizations "Revenue Watch" and "Transparency International".

In recent years, very important measures were taken in the direction of sustainable development of human capital. One of the great services of our nationwide leader Heydar Aliyev in bringing the development of education and science into a high level was the achievement in sending 47 students to abroad in 1969 when our country had yet been in the structure of Soviet Union and this figure was reached to 1400 persons in 1980. In modern period, state programs are being realized according to the orders signed by the country' President, Mr. Ilham Aliyev for the purpose of the development of education. As an example to these, "State Program on the education of Azerbaijani youth in abroad in 2007-2015", "Program on the provision of schools of Azerbaijan Republic with ICT (2005-2007)", "State Program in the informatization of education system in Azerbaijan Republic in 2008-2012" can be shown.

So, professional young staff of Azerbaijan are forming main basis for transfer of scientific, technical and cultural innovations of modern world to our country in reputable scientific and educational institutions of both within republic and foreign states. They can be considered as gold fund of modern management technology. So it can be also noted that government takes purposeful steps related to the increase in the number of young people who study in foreign countries, and also to increasing their study costs. So, revenues obtained from oil and gas resources are directed to the development of human capital and turn into reliable guarantee for the economic progress and sustainable development of Azerbaijan.

At the same time, in 2009 decree of country's President signed related to the establishment of Science Development Foundation under the President of Azerbaijan Republic is an example for the aforementioned. Foundation is aimed in simulation of scientific researches in Azerbaijan, strengthening of exploration of the country's natural resources, cultural and historical heritage, increasing effectiveness of researches in various spheres of science, representing Azerbaijani science worthily among the world scientific community. (http://sdf.gov.az/qrant/eif_info_eng.pdf) Establishment of such a fund and events more often held by it and grant competitions stimulate and give motivation for the enhancement of young scientists' creativity opportunities and to show their potentials.

“Azerbaijan 2020: Look into the Future" Development Conception approved by the decree of President Ilham Aliyev in 2012 occupies an important place among the implemented measures. Main purpose in the development of conception is to provide the sustainable and balanced development of country's economy, increase social welfare of population and to form new model of development in terms of quality by accelerating the progress in all directions of the society. Development of human capital occupies central position in the conception. Fund allocated for education, science, health, social protection, culture and sport from state budget was 4325,4 million manat in 2012 and this is 10,8 percent more than from the indicators of the last year. All of these once more prove that there is taken enough serious action in this direction in Azerbaijan. As a result of it, Azerbaijan obtained special place among rapidly developing countries in the world in terms of economy.

According to the aforementioned, it can be said that there have been implemented enough significant measures in the direction of "turning oil capital into human capital" in Azerbaijan and the results of it shows themselves. However there is a need for the implementation of a number of measures in order to provide the full development of this field. And this will be implemented by the Ministry of Education.

At present, Azerbaijan is considered leader state in South Caucasus according to the rate of its socio-economic development. As a result of the implemented great reforms, various infrastructure projects, dynamic development in the country has obtained sustainable nature. According to the report of Human Development program of UNO, when Azerbaijan was ranged as $101^{\text {st }}$ range in 2005, it ranged $82^{\text {nd }}$ place on the basis of the results of 2013 and it was achieved to take $76^{\text {th }}$ place among 187 countries in 2014. (Human Development Report, 2014)

\section{Conclusion}

In the end, we can conclude that oil and gas resources have played an important role in the history-pass and in present condition of our country and it will not lose its importance for several years after that. Just for those natural resources our country has become the center of completion within the realm of interest of great states for 
many years. It is right, in this case our state is obliged to take balanced policy, that's cooperate with traditional states of region and also with super powers of the world. Just it is a result of this consistent policy that USA's relations which is considered super power of the world with Azerbaijan is in strategic partner hip level though its relations with Russia and Iran which are big states of the region. Though all these difficulties, we achieved to go forward. Sometimes various specialists relate the development of Azerbaijan with energy. That is right oil played an important role in the transformation of Azerbaijan. However if we will analyze this, we could see that we achieved to use our oil revenues in a clever and wise manner. The activities of the president in the sphere of supporting young generation and improving the education system have been increasing year by year. It is true that today is still too early to compare our schools, universities with the world's leading educational institutions. Our country gained independence approximately 25 years ago. But our 25 years of achievements show that, if development continues in this pace, soon the education system will meet the standards of the world.

\section{Acknowledgements}

I express my sincere appreciation to my Supervisor Professor Dr. Karam Mammadov for his guidance, invaluable insight and encouragement in the process of writing this paper. He has been always helpful throughout this process, his valuable comments and supportive guidance was important for me. I also thank to the members of the Scientific Research Institute on Human Rights, in particular, the Director of the Institute of Dr. Ayten Mustafayeva for their tolerance, valuable suggestions and comments. And last but not least, I would like to thank my family for their trust and faith in my academic skills, especially I want to thank to my husband for being with me as the closest friend.

\section{References}

Azerbaijan and United States: Tested and proven allies. Retrieved from http://www.afaz.org/azerbaijan-andunited-states-tested-and-proven-allies/

Briefly about the Science Development Foundation under the President of the Republic of Azerbaijan. (2009). Retrieved from http://sdf.gov.az/qrant/eif_info_eng.pdf

Bunyadov, Z. (1994). History of Azerbaijan (Vol. 1, p. 326). Baku, Azerbaijan State Publishing House.

Bush, G. H. W. (1991). President's speech from the Oval Office to the United States on the resignation of Soviet President Mikhail Gorbachev, December 25. Retrieved from http://www.c-span.org/video/?23549-1/address -gorbachev-resignation

Frederick, S. S., \& Svante, E. C. (2005). The Baku-Tbilisi-Ceyhan Pipeline: Oil window to the West. Central Asia-Caucasus Institute and Silk Road Studies Program. Retrieved from http://www.silkroadstudies.org/ BTC.pdf

Gassimov, M., \& Abdullayev, M. (1998). History of International Relations: XX Century (p. 294). Part 1, 1990-1945. Baku.

Hasanli, J. (1993). Azerbaijan-American relationships (1918-1920). Azerbaijan, 42(291).

Hasanov, A. (2005). Contemporary International Relations and Foreign Policy of Azerbaijan (p. 550). Baku.

Human Development Report 2014. Sustaining Human Progress: Reducing Vulnerabilities and Building Resilience. Published for the United Nations Development Program. Retrieved from http://hdr.undp.org /sites/default/files/hdr14-report-en-1.pdf

İsmayılov, E., Hasanov, J., \& Gafarov, T. (1995). History of Azerbaijan. Baku, Oyretmen Publishing.

List of countries by oil consumption. Retrieved from http://en.wikipedia.org/wiki/List_of_countries_by_ oil_consumption

Schultz, T. W. (1981). Investing in People: The economics of population quality (p. 173). University of California Press.

State Oil Fund of the Republic of Azerbaijan: Mission, goals and philosophy. Retrieved from http://www. oilfund.az/az_AZ/about_found/meqsed-ve-felsefe.asp

The Contract of the Century. Retrieved from http://www.azerbaijans.com/content_775_az.html

The Millennium Development Goals. (2000). Issued by the UN Department of Public Information. Retrieved from http://www.un.org/en/mdg/summit2010/pdf/List\%20of\%20MDGs\%20English.pdf

\section{Copyrights}

Copyright for this article is retained by the author(s), with first publication rights granted to the journal.

This is an open-access article distributed under the terms and conditions of the Creative Commons Attribution license (http://creativecommons.org/licenses/by/3.0/). 